\title{
MANAGEMENT OF ABANDONED LAND IN THE PERSPECTIVE OF ISLAMIC LAW AND NATIONAL LAW OF LAND
}

\author{
Ridwan \\ (Faculty of Sharia, IAIN Purwokerto Jl. A. Yani No. 40 A. Purwokerto, \\ Email: ridwanparadise@yahoo.com)
}

\begin{abstract}
:
This article is aimed at showing that land has not only economic values, but also social values. Abandoning land indicates ignorance to both values and is against legal norms, both religious and state norms in Indonesia. The consequence of abandoning land by the owner, either in Islamic or national law perspective, will result in the banning of the rights of its possession by the state who has the authority to manage the use of land for social welfare. This article proves that both Islamic and national laws have a similarity in the basic law aspect, that land should have social and economic functions. The state has the juridical authority to ensure that land is used for social welfare, including assuring that there is no land abandoned by its owner.
\end{abstract}

\section{Key Words: \\ Abandoned Land, Islamic law, National Law, Social Functioning, and Social Well-being}

\begin{abstract}
Abstrak:
Artikel ini menunjukkan bahwa tanah di samping bernilai ekonomis, juga memiliki nilai sosial. Penelantaran tanah menunjukkan, selain adanya pengabaian terhadap kedua nilai tersebut, juga bertentangan dengan norma hukum, baik hukum Islam maupun hukum positif Indonesia. Konsekuensi penelantaran tanah yang dilakukan oleh pemilik tanah baik menurut hukum Islam maupun hukum nasional mengakibatkan pemerintah sebagai pemilik otoritas memiliki kewenangan untuk menarik kembali dan menjadikan tanah tersebut untuk kemaslahatan sosial. Artikel ini membuktikan bahwa antara hukum Islam dan hukum nasional memiliki kesamaan pada aspek hukum asas bahwa tanah harus memiliki fungsi sosial. Negara memiliki otoritas untuk memastikan bahwa tanah harus bias menjalankan fungsi kemaslahatan sosial termasuk menjamin tidak adanya tanah yang ditelantarkan oleh pemiliknya.
\end{abstract}

al-1hkâm Vol.11 No.1 Juni 2016

DOI: http://dx.doi.org/10.19105/al-ihkam.v11i1.855 
Kata-kata Kunci:

Tanah Terlantar, Hukum Islam, Hukum Nasional, Penfungsian Sosial, dan Kemaslahatan Sosial

\section{Introduction}

The existence of land precedes human presence in the world. ${ }^{1}$ Land $^{2}$ is an important production factor, so that land ownership should be distinguished from other factors of production. As an overview of the importance of land position, in Islamic law, it is stipulated that if the owner of land abuses the rights of land ownership, then the state has the authority to force the land use properly or even retract the ownership to be given to others in order that the land is more useful. ${ }^{3}$

The function of land in Islam is different from the concept of land prevailing in Europe in the middle age, at the inception of capitalism ideology. At the time of the French revolution, the social perception of property rights of land was based on the belief that property rights was seen as sacred and noble right so that such rights should not be reduced by other parties. The right to land is seen as an absolute right. Social beliefs that the owner is the full ruler of his property have led to the birth of the belief that the owners have greater freedom to treat their property as they wish. ${ }^{4}$ The owner can

\footnotetext{
1 According to Michael McElroy (chairman of the Harvard University, Department of Earth and Planetary Sciences), the earth's evolution has occurred since 4.6 million years ago, followed by the evolution of humans (Homo sapiens) which emerged as a community on earth since 150,000 years ago. See further details in Mary Evelyn Tucker and John A. Grim, "Introduction: The Emerging Alliance of World Religions and Ecology" Deadalus. (130, 4 (2001), 2.

2 According to Marshall, the word land especially in the economic sense encompasses a broad sense. It includes everything that is found or attached to the land such as river flow, sunshine, rain, air and waterfalls which are all positioned as a production tool. See, Alfred Marshall, Principles of Economics (London: Macmillan and Co., Limitted ST. 1952), 120.

3 Afzalur Rahman, Economic Doctrines of Islam, Vol. 1, Transl. Soeroyo and Nastangin (Jakarta: PT Bhakti Waqf Dhana, 1995), 312.

4 The strengthening of individualism, resulting in sanctification of private property rights enjoyed by the bourgeoisie is admitted by Marx and Enggels that it inspires them to mobilize the workers (proletarians) to demand their humanity rights in
} 
use the land for residence, place to run a business, plantations or even totally neglect it. ${ }^{5}$ The concept of individual freedom of land ownership is referred to as eigendom right, namely full ownership rights of a person to land that is infinite, in the name of individualism. ${ }^{6}$ Individualism has given birth to the attitude of the deification of the individual ownership as an absolute right.

In the history, land ownership in Islam is done through many ways, one of which is through the process of the conquest of the region and the acquisition of no man's land (al-mawat), namely the land that is not managed and is not owned by anyone, then the land belonged to the state and should not be owned by individuals unless it is mandated by the state to manage and that would be kharraj land. ${ }^{7}$ Normative arguments of state ownership of the land is based on the Q.S Anfâl 8:18 and three Hadits of the Prophet; first" 'Adi Land belongs to Allah and His Messenger, then belong to you"s; second, "Anyone who takes inch of land without right, then he will be weighted down with seven layers of the soil"; third, "Whoever revive 'dead' land, then the land is his, and no rights for those wrongdoers ".

accessing capital/profit better in the presence of the capital owner, they even demand "the abolition of private property". See further details in Karl Marx and Friedrich Engels, "Manifesto of the Communist Party", in the Lewis S. Feuer, Marx and Engels: Basic Writings on Politics and Philosophy, (New York: Doubleday \& Commpany, Inc., 1959), 20-21.

5 Sudargo Gautama, Pembaharuan Hukum di Indonesia (Bandung: Alumni, 1973), 41.

${ }^{6}$ In relation to individualism, Christian Schubert states that Individualism a social theory or ideology which assigns a higher moral value to the individual than to the community or society, and which consequently advocates leaving individual free to act as they think most conducive to their self-interest. See further in Christian Schubert, "A Note the Principle of Normative Individualism", The Paper on Economics and Evolution, Max Planck Institute of Economics Jena Germany, 2.

7 Abû Yusûf Ya'qûb ibn Ibrâhim, Kitâb al-Kharraj (Pakistan: Idarat al-Qur'an wa 'Ulum al-Islamiyyat, 1987), 65-66. Compare with `Adnân Khâlid, al-Madzhab al-Iqtishâdî alIslâmî (Jidah: Maktabah al-Sawady, 1990), 288.

${ }^{8}$ Q.S al-Anfâl (8): 1 which means "They ask you, [O Muhammad], about the bounties [of war]. Say, "The [decision concerning] bounties is for Allah and the Messenger." So fear Allah and amend that which is between you and obey Allah and His Messenger, if you should be believers".

9 Muhammad ibn Ismâ'îl al-Shan'ânî, Subûl al-Salâm, Vol. 3, (Beirut: Dâr Ihyâ alTurats, 1379 H), 83. See also, 'Alî ibn Mûsa Abû Bakr al-Bayhaqî, Sunan Bayhaqî alKubrâ, Vol. 6, (Makkah Mukarramah: Maktabah Dâr al-Baz, 1994), 143. 
The cause revelation of Q.S Anfâl 8:1 stems from the number of people who asked the Prophet to provide their share of spoils of war. The revelation of this paragraph proves that the spoils of war belong to Allah and His Messenger. ${ }^{10}$ Therefore, the authority to distribute them is on the Prophet as the head of government. This verse also confirms that the spoils of war, including land, belong to the state and should not be owned by individuals permanently. State ownership of spoils of war gets its justification through the hadits of the Prophet, which means "No one has the right to deadland, except those who are the desired by imam / head of state". 11 Thus, the basic principle of 'dead' land ownership is on the state control.

The interpretation of the hadits above, according to Quthb Ibrahim Muhammad, contains some conclusions. First, land is a property of God as the ultimate owner. Second, land is a state property and not the property of the state authorities. Third, the state is obliged to manage the distribution of land rights based on the value of common benefit. Fourth, granting land rights to someone not as an absolute property rights as suggested by the Prophet; whoever takes the land without right then he is threatened weighted down with seven layers of soil. Fifth, there must be legalization from the government regarding the land ownership of a person

Regulation of land issues in the context of Indonesia was stipulated in Law No. 5 of 1960 on the Basic Regulation of Agrarian. Basic Agrarian Law (hereinafter abbreviated as BAL). The central concept of the Law is the rules of land ownership, 12 concerning the legal relationship between the land and the owners with the rights and obligations attached to the ownership. The presence of BAL encourages populism spirit oriented to the recognition of the land

$101 / 5$ of the overall spoils are for Allah and Rasululllah. As a prophet and head of state, the Prophet entitled to the spoils of war as a gift of God. However, the Prophet himself states that the one - fifth is given back to Muslims.

11 'Alî ibn Abî Bakr al-Haytsâmî, Majma' al-Zawâ'id, Juz 5 (Bairut: Dâr al-Kutub alArabî, 1407), p. 331. See also, Ahmad ibn Saîd ibn Hazm al-Zhâhirî, al-Muhalla, Juz VIII, (Beirut: Dâr al-Âfâq al-Jadîdah, t.tp), 234.

12 What is meant by the Land in the BAL formula described in chapter 4 is the earth's surface which also includes part of the earth laying beneath the earth and some space on it. See, Boedi Harsono, Hukum Agraria Indonesia: Sejarah Pembentukan Undangundang Pokok Agraria, Isi dan Pelaksanaannya (Bandung: Djambatan, 2007), 262-263. 
rights of people and the distribution of state land for the benefit of the people. ${ }^{13}$

Each private property will always be in contact with a variety of interests of other parties. The connection of interests can take the form of relationship amongst individuals, between the individual and society, and between the individual and the state. The connection point relates to a variety of interests arising from many interests around the individual ownership of land which often leads to disputes over land rights. One of the issues which arises in connection with the land issue is regulation of clearing no man's land or neglected land for individual property. Individual rights will be in contact with public authorities, namely the state in connection with the acquisition of right to the land.

This article will elaborate law of abandoned land management in Islamic perspective and the national land law. With reference to the sources of classical Islamic literature and regulations of Indonesia, the limits of neglected land will be explained, as well as legal position of the ownership of the abandoned land and its management. Various concepts of neglected land in Islamic law are discussed with the national land law to formulate a common point and the relevance between the two.

\section{The Law of Abandoned Land Ownership}

Land as property which has economic value has special characteristics in terms of acquisition. Acquisition of right to land is originair in nature, meaning that it is given from God in which its raw materials are already there before birth. ${ }^{14}$ It is in contrast to other property ownership which is derivative, meaning that it is acquired through hard work of human. ${ }^{15}$

According to Joseph Schacht 16 viewed from the origin, the system of ownership in Islam can be divided into two kinds; the

13 Noer Fauzi, Bersaksi untuk Pembaruan Agraria: Dari Tuntutan Lokal Hingga Kecenderungan Global, (Jogjakarta: INSIST PRESS, 2003), 25.

14 Tucker and Grim, "Introduction " Deadalus. (130, 4, 2001), 2.

15 Alfred Marshall, Principles of Economics (London: Macmillan And Co., Limitted ST. 1952), 123.

16 Joseph Schacht, Pengantar Hukum Islam, Transl. Joko Supomo (Jakarta: Islamika, 2003), 205. 
original ownership and the ownership which comes from other people. First, the original ownership is acquired through the acquisition of objects with no previous owners (res nutlius). This category encludes the ownership of the treasure findings (rikaz, $m a^{\prime} a$ dîn), ghanimah treasure (spoils of war) or luqathah. Second, the ownership which comes from other people either through grants, contract or warranty. Acquisition of the land that has no owner or land abandoned by its owner is called the ihyâal-mawât.

In the books of figh, ihyâ al-mawât is defined by scholars with different wording. Ibn Hajar al-Asqalânî (773-852) defines ihyâ almawât as one's attempt to make use of land that is not owned by anyone by planting, irrigating or building on the land. ${ }^{17}$ Abû Ishâq alSyirâzî argued that in islamic jurisprudence ihyâ al-mawât is categorised as Sunnah (recommended) as the implementation of the Prophet's orders. ${ }^{18}$ What is meant by abandoned (al-mawât) is a land that has not worked by anyone. ${ }^{19}$ In general, the abandoned is land that is difficult to cultivate due to the lack of irrigation water, or landforms that are infertile and have never been cultivated by anyone. ${ }^{20}$

The criteria of abandoned land in the view of Islamic law as stated above is different from the concept of abandoned land found in the Government Regulation No. 36 of 1998 on Control and Utilization of Abandoned Land. It is stated in the General Provisions of Government Regulation that the definition of abandoned land is land that is abandoned by those who have the right to the land, who have the right to make use of the land or those who have acquired basic

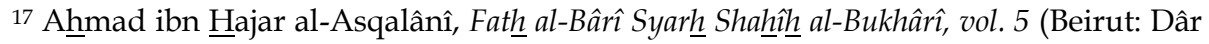
al-Ma'rifah, $1379 \mathrm{H}), 18$.

18 Abû Ishaq al-Syirâzî, al-Muhadzdzab fi al-Figh al-Imâm al-Syâfi'î, Vol. 1 (Beirut: Dâr al-Fikr, T.tp), 423. See also, Syihâb al-Dîn al-Ramlî, Nihayat al-Muhtaz ila Syarh alMinhaj, Vol. 5 (Mesir: Musthafâ al-Bâb al-Halabi wa Awlâduhu, 1375 H), 327. See also, Muhammad al-Khathîb al-Syarbînî, Mughni al-Muhtaj ila Ma'rifah Alfâzh al-Minhaj, Vol. 2 (Beirut: Dâr al-Fikr, T.tp), 361.

${ }^{19}$ Abû Zahrah, al-Milkiyât, p. 108. See also, Mahnûd ibn Ibrahim al-Khâtîb, al-Nizhâm al-Iqtishâd al-Islamî fi al-Islâm (Riyadl: Maktabah al-Haramayn, 1989), 94. See also, alRamlî, Nihayat al-Muhtaz, p. 327.

${ }^{20}$ Muhy al-Dîn ibn Syaraf al-Nawâwî, al-Majmû‘ Syarh al-Muhadzdzab, Vol. 16 (Beirut: Dâr al-Fikr, T.tp), 82.
} 
tenure under the provisions of the legislation in force. ${ }^{21}$ Thus, in this formulation abandoned land is land that has been the right of someone but then abandoned by the owner in accordance with the circumstances or the nature and purpose of the right, or is not maintained properly. It is also described in the government regulation that land whose tenure has been acquired, but the right to the land has not obtained in accordance with the legislation in force can be classified as abandoned land, when the right to the land is not requested nor maintained properly by those who have obtained the basic tenure. ${ }^{22}$

Broadly speaking, the land territory of the Islamic state according to al-Syâfi'î ${ }^{23}$ is divided into two types: inhabited land (al'amir) and 'dead' land (al-mawât). As for the inhabited land, the ownership of it is on person who occupies it. As for the 'dead' land, it is divided into two categories. First is land that has never been owned by anyone or has not been found indications which mark that someone has once worked on the land (no man's land). Second is abandoned land in which someone has once owned it. Both types of the land can be owned by the way of ihyâ al-mawât.

The legal status of the 'dead' land which has once owned by a person (abandoned land) is divided into three types. First is land owned by certain people and in certain ways. If the ownership of the land is acquired through purchase or grant from others, then the land should not be managed by the way of ihyâ al-mawât. However, if the ownership of the land is acquired through the ihya al-mawat and then the land is abandoned, then the legal status of the land is that it may be managed by anyone who is willing through ihya al-mawât. Second is land in ancient times (at the age of ignorant) such as the wealth of the Roman and buildings of Thamud people. such land can be owned by the way of ihyâ al-mawât, because their ownership has no value of glory. Third is land which was once owned by a person at the time of Islam, both owned by Muslims or non-Muslims. Scholars have different opinion on this type of land. According to Ahmad ibn

21 Act No. 36 of 1998 on Control and Utilization of Abandoned Land, Article 1 paragraph 5 .

22 Act No. 36 of 1998 on Control and Utilization of Abandoned Land, article 8, paragraph 1.

${ }^{23}$ Muhammad ibn Idrîs al-Syâfi'î, al-Umm, Vol. 4, (Beirut: Dâr al-Ma'rifah, 1393 H), 41. 
Hanbal the land cannot be owned by the way of ihyâa al-mawât. Meanwhile, according to Hanafî and Mâlikî, the land may be owned by the way of ihyâ al-mawât based on general wording of a hadits. If the land is in an Islamic country, the land is positioned as luqathah, and if the land is located in an enemy territory, the legal status of the land is the same as rikâz..24

The characteristics of 'dead' land, according to al-Nawâwî alDimasyqî (d. $676 \mathrm{H}),{ }^{25}$ can be divided into two types; 'dead' land which is located in a Muslim country and the land that is in enemy territory. The legal status of the land that is in Islamic country can be broken down into three kinds. First, if the land has not been managed either in the past or now, it can be owned through clearing either with permission or without permission from the government. Second, if the land that is managed by a person at present, then that person becomes the owner.

Based on the opinions of figh scholars mentioned above, the perspective used in seeing the status of land is territorial boundaries on the basis of the ideological category of countries, namely between the Islamic state and non Islam state. The different territorial classification has an effect on the legal status of the land to be cleared. The legal distinction of abandoned land using territorial-ideological boundaries is different from that in Government Regulation No. 36 of 1998 on Control and Utilization of Abandoned Land in which the land is positioned within the territory of Indonesia and is declared as abandoned land because it is deliberately abandoned by the owner. According to the author, in the context of abandoned land ownership regulation both in Islamic law and national law grounded in the same spirit of law, namely all land should be positioned as productive land so that the land can function socially.

The legal principle of the abandoned land in the BAL is included in a special category of law because it is mentioned in the Agrarian Law which encompasses; the First is the principle of the social function of land rights. The second is the principle of prioritizing

24 `Abd Allâh ibn Aḥmad ibn Muhammad ibn Qudâmah al-Maqdisî, al-Mughnî, Vol. 8 (Cairo: Markaz al-Buhûts wa al-Dirasât al-Arabiyyah wa al-Islâmiyyah, T.th), 146147.

${ }^{25}$ Muhy al-Dîn ibn Syaraf al-Nawâwî al-Dimasyqî, Rawdlah al-Thâlibîn, Vol. 4 (Beirut: Dâr al-Kutub al-Ilmiyyah, T.th), 344-348. 
general interests. The third is the principle that prohibits the use of land which does not agree with the nature and purpose of the rights. The fourth is the principle of good will from those who have a relationship with the land in exercising their rights and obligations. ${ }^{26}$

In Islamic law, land is declared as dead/abandoned land when it is far away from residential areas. ${ }^{27}$ There is a disagreement amongst scholars in terms of the distance of the land die with settlements. In this regard, according to Hanafi it can be measured by the way of a person standing near the abandoned land and then he shouts out with the loudest voice. If his voice could not be heard in the residential areas, then it can be considered as far. ${ }^{28}$ Otherwise, if his voice could be heard, it can be considered as close. Other figh scholars do not question the distance because the standard of the distance can be left to the tradition adopted by the community, this is stated by Ahmad ibn $\underline{\text { Hanbal }}$ and al-Syâfi'î schools.

How to get property rights to land through new land clearing in the legal concepts of land Indonesia has lasted long as the legal system that is alive and flourishing in Indonesian society. The acquisition begins with the forest clearing by a communion member with the knowledge of the head of the communion, followed by the installation of marking and processing of land into garden or farm. If the relationship between him and the land is already fixed, then the relationship gradually becomes relationship of property rights.

In Islamic law, land is regarded as 'dead' land when in reality, the land is not a public facility owned by community collectively. The

26 Suhariningsih, Tanah Terlantar: Asas dan Pembaharuan Konsep Menuju Penertiban (Jakarta: Prestasi Pustaka, 2009), 240.

27 Al-Kissânî, for example, sets criteria of abandoned land (al-mawât) in his book Bada 'i al-Shanâ' $\hat{\imath}$ : فالأرض الموات هي أرض خارج البلد لم تكن ملكا لأحد ولا حقا له (abandoned land of al-mawat) is a land that is outside the State land, and yet has no owner. See further details in 'Ala aldîn al-Kissânî, Bada'i al-Shanâ'î, Vol. 6 (Beirut: Dâr al-Web al-Arabî, 1982), 194. Meanwhile, Muhammad 'Abd al-Jawwab offers other criteria, saying that the abandoned land is land that is outside the state land that are far away from residential areas or away from agricultural land. See more details Muhammad 'Abd al-Jawwab, Buhûts fi al-Syarî'ah al-Islâmiyyah wa al-Qanûn (Cairo: Jami`ah al-Qâhirah, 1977), p. 187. Compare to al-Nawâwî, al-Majmû Syarh al-Muhaddzab, Vol. 16, 82.

${ }_{28}$ Muhammad ibn Sahl al-Sarakhsî, al-Mabsûth, Vol. 23 (Beirut: Dâr al-Ma'rifah, 1406 H), 166 . 
basic principle of ihyâ al-mawât is clearing land which has not been adhered by a right.

In terms of legal status of abandoned land (al-mawât) ownership, scholars have different opinion; First, if the land is the property of a muslim or dlimmî infidel, while its owner is unknown, according to Ahmad ibn Hanbal, the land cannot be categorized as abandoned land as long as the ownership rights is obtained after a period of muslim rule. The legal basis used by Ahmad ibn $\underline{\text { Hanbal is a }}$ hadits, "Whoever clears 'dead' land that is not owned by Muslims, the land belongs to those who clear it". According to Ahmad ibn $\underline{\text { Hanbal if }}$ the owner is not known, it does not mean that the land ownership disappears. If the owner is not known for certain, then the ownership rights are transferred to his heir. Secondly, clearing the abandoned land according to Abû Yusûf, al-Syâfi'î and Ahmad ibn Hanbal, (the opinion of majority of scholars) does not need any permission from the government (imam). Meanwhile, according to Abû Haniffah it needs the permission from the imâm. ${ }^{29}$

The reason of the first opinion (al-Syâfi'î and Ahmad) is that the abandoned land does not belong to a bayt al-mâl but is a neutral treasure (permissible) and in this case, those who first take it (worken on it) then become the owner, and it is the same as those who hunt animals that has no owner. ${ }^{30}$ If hunting is a way of acquisition of property rights without permission of the imâm, then clearing land also does not need permission. The right to clear the land is the right of all muslims who have the ability, according to law, to manage the property as a legal subject. ${ }^{31}$ Thus, the ownership is there because of a direct mandate from Allah (al-Syâri'). ${ }^{32}$

\footnotetext{
29 al-Nawâwî, al-Majmî Syarh al-Muhadzdzab, Vol. 16, 82. See also, al-Maqdisî, alMughnî, Vol. 8, 182 see also, 'Isa 'Abduh, al-Nuzhûm al-Mâliyah fi al-Islâm (Cairo: Ma'had al-Dirasat al-Islâmiyah, T.tp), 219. See also, al-`Asqalânî, Fath al-Bârî, 18. See also, Muhammad ibn Ahmad al-Minhâjî, Jawâhir al-'Uqûd wa Mu'în al-Qudlat wa Muwaqqîm wa al-Syuhûd, Vol. 1 (Beirut: Dâr al-Kutub al-Ilmiyyat, 1996), 238.

30 al-Syirâzî, al-Muhadzdzab, 423; al-Syarbînî, Mughnî al-Muhtaj, 361.

31 al-Syirâzî, al-Muhadzdzab, 423

32 The content of the hadits is " وليس لعرق ظالم عرق" من احيا ارضا ميتة فهي له See al-'Asqalânî, Fath alBârî, 19. See also, Mâlik ibn Anas, al-Muwatthâ', Vol. 2 (Mesir: Dâr Ihya' al-Turâts alArabî, T.tp), 742.
} 


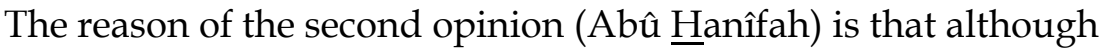
the abandoned land has no owner in Islam, the status of the land is in control of the government (imâm). ${ }^{33}$ Jurisdiction power of the imam in a country is the basis of the authority of ownership. Based on this thought, then no one is in control of something without the permission of the imâm. The legal basis to which Abû Hanifah refers is the hadits of the Prophet "ليس للمرءالا ماطابت به نفس املمه" ". Therefore, no man's land is under the imâm's control,34 including the distribution system and target determination which are the authority of the government to regulate them. ${ }^{35}$

Argument put forward by Abû Hanîfah as stated by Abû Yûsuf is that if clearing an abandoned land is not through the permission of imâm, it will lead to fight and conflict. ${ }^{36}$ As for the hadits of the Prophet "من احيا ارضا ميتة فهي له", it should not be understood as without a condition of permission. The meaning of the hadits above is similar the meaning of hadits "من قتل قتيلا فله سلبه "No one of scholars who thinks that the meaning of the hadits is anyone who fights jihâd fi sabilillah by itself he is entitled to take salab (spoils of war) without permission from the imâm. According to Abû Hanifah, considering the two haditss above, it is clear that the haditss imply the need for permission from imâm in order to avoid conflict, although it is not described in the text explicitly. ${ }^{37}$

\footnotetext{
33 According to Muhammad `Abd al-Jawwab Muhammad, almost all countries today states that all land that has no owner is considered as state-owned land. Therefore, it is obliged to have permission from the government to clear/revive abandoned land. See further details in 'Abd al-Jawwab Muhammad, Buhûts fi al-Syarî'ah, 187. See also, Abû Yûsuf Ya'qûb ibn Ibrâhim, Kitâb al-Kharraj (Pakistan: Idârah al-Qur'ân wa 'Ulûm al-Islâmiyyat, 1987), 64.

34 Ibn Ibrâhim, Kitâb al-Kharraj, 58-59. See also Abû 'Ubayd al-Qâsim ibn Salâm, Kitâb al-Amwâl (Beirut: Dâr al-Kutub al-Ilmiyah, 1986), 297-298.

35 S.A. Siddiqi, Public Finance in Islam (New Delhi: Adam Publisher \& Distributors, T.tp), 76.

${ }^{36}$ Ibn Ibrâhim, Kitâb al-Kharraj, 63. See also, al-Sarakhsî, al-Mabsûth, Vol. 23, 167.

37 Abû Zahrah al-Milkiyat wa al-Nazhariyat al-`Aqd. 111-112. In the view of Muhammad Abd al-Jawwab Muhammad clearing abandoned land does not need permission from government. This view is supported by al-Mâlikî, al-Syâfi'î, Hanbâli and al-Zhâhirî which is the opinion of the majority of figh scholars. The view which states that there has to be a permission from the government in clearing abandoned land is the opinion of Abû Hanîfah and Shi'ite al-Ja'farî. The second opinion is precisely the
} 
From the description of the different opinion maps amongst scholars above, in the view of the author, the opinion of Abû Haniffah which requires having a government permission seems to be more relevant in the present context, since it implies land ownership which shows more dimensions of public and necessitates the government's role in regulating the legal issues of land. The government has the authority to govern the ownership of land, in terms of both the way of acquisition and allocation in order to minimize the rise of social conflicts caused by land ownership disputes.

Technically, clearing the abandoned land can be done by giving clear boundaries on the land indicating that the land is already managed by someone. Another sign that could be used is by cutting thorns found on the land or flatten high land. However, marking the land does not necessarily mean that the ownership right is given to those who clear the land. It is only given to those who manage the land well become productive land. ${ }^{38}$ According Ahmad ibn Hanbal and Abû Hanîfah both Muslims and non-Muslims (dlimmî) have the same rights to clear no man's land, while according to the Mâlik, a dlimmî has no right to clear new lands in Islamic country areas. ${ }^{39}$

Another debate over the legal relationship between the abandoned land by their owners is whether it is obliged to pay kharraj (tax) on abandoned land that has already managed as al-aradli alkharrajiyah or it is obliged to pay one tenth as al-aradlî al- 'ushriyyah. In this case, figh scholars differ in setting their legal status. If it is the dhimmi who clears the land, then he is obliged to pay kharraj, although the ownership rights have been transferred to others. If the land is cleared by a Muslim, then he is obliged to pay one-tenth. According to Abû Haniffah, if the ownership of the abandoned land by a Muslim is transferred to dlimmî, then the obligation is to pay kharraj. so, it depends on who first cleared the land. In addition, the obligation of paying one-tenth is similar to that of zakat as a part of worship. Therefore, a worship performed by non Muslims is refused.

reference of land laws in the times of the Utsmaniyah caliph, and several Arab countries including Saudi Arabia. See further details in `Abd al-Jawwab Muhammad, Buhûts fi al-Syarî'ah al-Islâmiyyah, 190.

38 Abu Zahrah, Al-Milkiyat wa al-Nazhariyat al-Aqd, 112.

39 al-Maqdisî, Al-Mughnî, Vol. 8, 148. 


\section{Managing Abandoned Land}

With regard to clearing abandoned land, Muhammad 'Abd alJawwab Muhammad divides it into two ways. The first is al-tahajjur that is land clearing technique by providing borders to the land to be cleared by placing a pile of rocks or other marks that could be understood as a sign that the land has been already owned. The second is al-ihyấ land clearing technique by managing or cultivating certain area of land that can be understood socially that the land has been cultivated. Ihyâ' al-mawât marking can also be done by setting up a wall fence around the land to be clear or by building irrigation system if it is intended for agricultural land. ${ }^{40}$

If a person has made boundaries of the abandoned land, then he becomes the most entitled person to manage the land amongst other people. Then, if there are other parties to seize and manage the land, the one who manages the land has more right than those who set up the boundaries on the land. Meanwhile, if a new person who provides new boundaries on the land wants to sell the land before managing it first, then this person has not right to sell it according to obvious opinions in the school of Syafi'i, while many of the school of Syafi'i allow the person to sell it, since when he sets the boundaries on the land, then he becomes the one who has the right to the land. Therefore, he is allowed to sell it as his own property. If someone has set up boundaries on an abandoned land, then he drains water to the land but he does not cultivate it, then he becomes the owner of the water and the abandoned land which is watered as well as the edges. However, he could not own the rest of the land, although he remains as the owner or is entitled to the land. Then he also has the right to sell the land that has been watered. ${ }^{41}$

In the terminology of western Civil Law (BW), the concept of full and absolute ownership is called as eigendom. How to obtain the eigendom as stated in article 548 of BW can be done through 1). Taking

\footnotetext{
40 How to clear abandoned land will be different depending on the purpose. If clearing the new land is intended to be a residence, it can be done by building a proper house. If it is intended for farming, it can be done by spreading seeds or planting certain plants as well as making irrigation system. See, 'Abd al-Jawwab Muhammad, Buhûts fi al-Syarî'ah al-Islâmiyyah, 187-189. Compare to Nihâyat alMuhtaz, 335.

41 al-Mâwardî, Kitab al-Ahkâm al-Sulthâniyah, 178-179.
} 
(clearing land, fishing), 2). Natrekking, namely when an object becomes larger or doubled because of the nature (land gets larger as a result of earthquakes, a horse gives a birth, trees bear fruit, 3). Time (verjaring), 4). Inheritance, 5). Grant (levering) which is based on a title of transferring rights from the persons entitled to transfer the eigendom. ${ }^{42}$

Another debate over the legal relationship between the abandoned land by their owners is whether it is obliged to pay kharraj (tax) on abandoned land that has already managed as al-aradli alkharrajiyah or it is obliged to pay one tenth as al-aradli al-ushriyyah. In this case, fiqh scholars differ in setting their legal status. If it is the dlimmî who clears the land, then he is obliged to pay kharraj, although the ownership rights have been transferred to others. If the land is cleared by a muslim, then he is obliged to pay one-tenth. According to Abû Haniffah, if the ownership of the abandoned land by a muslim is transferred to dlimm $\hat{\imath}$, then the obligation is to pay kharraj. so, it depends on who first cleared the land. In addition, the obligation of paying one-tenth is similar to that of zakat as a part of worship.

Islamic law categorizes the subject (those who clear abandoned land), based on religious identity, as Muslim and nonMuslim subjects. Differences of religion status in fiqh perspectives lead to different obligations. This is in contrast to the national land law which puts the subjects not on the basis of religious category but the natives (WNI) and foreigners (WNA). In the national land law, all Indonesian citizens beyond the boundaries of ideology are entitled to land ownership acquired legally.

According to Muhammad Abû Zahrah (1898-1974), there are two possibilities of obligations of abandoned land managed by muslims; one-tenth or one-fifth based on irrigation systems of the land. If the land is watered from the rain or water of spring found in the lands being managed, then the obligation is one-tenth. However, if the water comes from wells dug by others (non-muslims) before Islam, then the obligation is kharraj.

The irrigation systems become the consideration for determining legal obligation because water is the most vital element in the management of land so that it becomes productive. ${ }^{43}$ Another

\footnotetext{
42 Subekti, Pokok-pokok Hukum Pedata (Jakarta: PT Intermasa, 1992), 70-71.
}

43 Abu Zahrah, al-Milkiyât, 116. 
problem associated with the ihy $\hat{a}^{\prime}$ al-mawât is technical issues on how to clear abandoned land so that it becomes one's property. In the view of Abû Hasan al-Mâwardî, the Prophet did not provide detailed technical guidance on how to open and manage abandoned land in order to be useful both as a residence area or for agricultural land. By paying attention to the legal provisions of both the legal system, then the same dimensions of both is the spirit to enable the land to be productive one so as to run its social function.

Some juridical arguments in this regard are the provisions of articles in the Law (BAL) which states that land management must not be neglected, among others, it is stated in article 27 that the land ownership is taken away when land falls to the state due to abandonment; Article 34 e: that cultivation right on land (HGU) is taken away because of abandonment; Article 40 e: that building right on land (HGB) is taken away because of abandonment. ${ }^{44}$

It can be concluded implicitly from the clauses governing abandoned land discussed above, that any land rights granted or obtained from the state such as freehold rights (HM), cultivation right on land (HGU), and building right on land (HGB) would terminate if the land is abandoned. As description as well as locally technical explanations in the management of abandoned land, a Decree of the Minister of domestic affairs No. 88 of 1973 on the ownership of abandoned plantation land in West Java Province. In the part of consideration of the Decree, it is stated that allowing farmland neglected or abandoned by the rights holder is a violation of a social function.

Subsequently, it was issued a new regulation on abandoned land, namely Government Regulation No. 36 of 1998 on Control and Utilization of Soil Abandoned Land. In Article 1, paragraph 5 Act No. 36,1998 it is stated that the abandoned land is the land abandoned by the holders of land rights, the holders of cultivation rights or those who have gained control over the land but has not yet obtained freehold right of the land in accordance with the provisions of Regulation in force. In connection with the loss of rights to abandoned land, there is a jurisprudence of the Supreme Court in its decision No. 239 / K / Sip / 1957 stated that right dispossession (rechtsverwerking)

44 Harsono, Hukum Agraria, 558-561. 
occurs when a piece of land acquired for 5 consecutive years is left by the owner. The state has the authority to take over the rights of the abandoned land, as an institution with the authority to regulate the use, the utilazation of land for the prosperity of the people.

In principle, normative stipulation of Islamic law with regard to the management of abandoned land is similar to that of the national land law in Indonesia. The requirement of land management in order to become productive land and run a social function, in the national land law or BAL is also the soul as well as the spirit of the Act. The philosophical reason is that the land is a gift from God to all mankind to be managed in order to achieve prosperity, common prosperity by adhering to the principle of fairness. ${ }^{45}$ Thus, land management is constitutional obligation for citizens who have the land so it does not become abandoned land. The reverse logic (argumentum a contrario) of it is that abandoning land rights is contrary to the spirit of the social function of land. ${ }^{46}$ By managing the land, one can bring social, economic and religious function of the land which will end in the creation of common benefits.

\section{Conclusion}

The regulation of abandoned land in the perspective of both Islamic law and the national land law is based on the same principle of law, that the act of abandoning land so as it is not productive and not be able to run its social functions is prohibited. Abandoning land, according to both legal systems, is part of a denial of the grace of God, which is the land that should be used for shared prosperity. Abandoned land that has not been adhered by property right is considered state land. Clearing abandoned land is one way of acquiring land rights.

The distinction between Islamic law and the national land law is in the legal qualification of the subject who clears/cultivates

\footnotetext{
${ }^{45}$ Communal and religious nature of the national land law, act no 5 of 1960 on Basic Regulation of Agrarian is described in Article 1 paragraph (2) which states that: "The whole earth, water and space including the natural resources contained within the territory of the Republic of Indonesia as a gift from God Almighty is the earth, water, and the space of Indonesia and are national assets ". See Harsono, Agrarian Law, 228.

46 Suhariningsih, Tanah Terlantar: Asas dan Pembaharuan Konsep Menuju Penertiban (Jakarta: Prestasi Pustaka, 2009), 111-112.
} 
abandoned land. In Islamic law, the subject is based on religious qualification which is a Muslim or non-Muslim, while in the national land law, the qualification of people who clear the abandoned land is based on qualifications of indigenous or foreigners.

\section{BIBLIOGRAPHY:}

Abû Zahrah, Muhammad. Al-Milkiyat wa al-Nazhariyat al-Aqd fî alSyari'at al- Islâmiyyah. Cairo: Dâr al-Fikr al-'Araby, 1996.

'Azhîm, Muhammad Syams al-Haqq. 'Awn al-Ma'bûud. Beirut: Dâr alKutub al-'Ilmiyyah, $1415 \mathrm{H}$.

'Asqalânî, ibn ㅂajar Abû al-Fadll. Fath al-Bârî, Beirut: Dâr al-Ma'rifah, $1379 \mathrm{H}$.

Bayhaqî, Abû Bakr. Sunan al-Bayhaqî al-Kubrâ, Makkah alMukarramah: Dâr al-Baz, 1994.

Fauzi, Noer. Bersaksi untuk Pembaruan Agraria: Dari Tuntutan Lokal Hingga Kecenderungan Global. Jogjakarta: INSIST PRESS, 2003.

Gautama, Sudargo. Pembaharuan Hukum di Indonesia, Bandung: Alumni, 1973.

Haytsamî, 'Alî ibn Abî Bakr. Majma' al-Zawâ'id. Beirut: Dâr al-Kutub al-'Arabî, 1407 H.

Harsono, Boedi. Hukum Agraria Indonesia. Djambatan: Jakarta, 2007.

Ibn Adam, Yahyâ. Kitab al-Kharraj. Cairo: Dâr al-Turâts, T.tp

Ibn Anas, Mâlik. al-Mudawwanat al-Kubrâ. Beirut: Dâr al-Shadr, T.tp.

Ibn Majah. Sunan Ibn Majah Juz 2. Beirut: Dâr al-Fikr, T.tp.

Ibn Qudâmah, Aḥmad ibn Muhammad. al-Mughnî. Beirut: Dâr alFikr, $1405 \mathrm{H}$.

Khâlid, 'Adnân. al-Madzhab al-Iqtishâdî al-Islâmî. Jedah: Maktabat alSawadi, 1990.

Kissanî, 'Ala' al-Dîn. Bada i' al-Shanâ'î. Beirut: Dâr al-Kutub al-'Arabi, 1982.

Marshall, Alfred. Principles of Economics. London: Macmillan and Co., Limitted ST. 1952.

Marx, Karl and Freidrich, Engels. "Manifesto of the Communist Party", in Lewis S. Feuer, Marx \& Engels. New York: Doubleday \& Commpany, Inc., 1959.

Mâwardî, Abû Hasan al-. Kitab al-Ahkkam al-Sulthâniyah. Beirut: Dâr alFikr, 1960. 
Muhammad, Muhammad 'Abd al-Jawwad. Buhhîts fi al-Syarî'ah alIslâmiyah wa al-Qanûn, Kairo: Jami' ah al-Qahira, 1977.

Muhammad, Quthb Ibrâhim. al-Siyâsah al-Mâliyah li al-Rasûl. AlHay'at al-Ushriyyah al-'Ammah, 1988.

-------. al-Siyâsah al-Mâliyah li 'Umar ibn Khaththab. Trans. Ahmad Syarifudin Shale. Jakarta: Pustaka Azzam, 2002.

Nawâwî, Muhy al-Dîn ibn Syaraf al-. al-Majmû' Syarh al-Muhadzdzab. Beirut: Dâr al-Fikr, T.tp.

Qasim ibn Salam, Abû Ubayd. Kitab al-Amwâl, Beirut: Dâr al-Kutub alIlmiyah. 1986.

Qazwaynî, Muhammad ibn Yazîd Abî ‘Abd Allah al-. Sunan Ibn Majah. Beirut: Dâr al-Fikr, T. tp.

S.A. Siddiqi. Public Finance in Islam. New Delhi: Adam Publisher \& Distributors, T.tp.

Shan'ânî, Muhammad ibn Ismâ'îl al-. Subîul al-Salâm. Beirut: Dâr Ihyâ al-Turats, $1379 \mathrm{H}$.

Sarakhsî, Muhammad Abî Sahl al-. al-Mabsîth li al-Sarakhsî. Beirut: Dâr al-Ma'rifah, 1406.

Schacht, Joseph. Pengantar Hukum Islam. Trans. Joko Supomo. Jakarta: Islamika, 2003.

Schubert, Christian. A Note the Principle of Normative Individualism. The Paper on Economics and Evolution, Max Planck Institute of Economics Jena Germany.

Syâfi'î, Muhammad ibn Idrîs al-. al-Umm, Beirut: Dâr al-Ma'rifah, 1393 $\mathrm{H}$.

Syarbînî, Muhammad al-Khathîb al-. Mughnî al-Muhtaj ila Ma'rifah Alfâzh al-Minhaj. Beirut: Dâr al-Fikr, T.tp.

------. al-Iqnâ' li al-Syarbîn̂. Beirut: Dâr al-Fikr, 1415 H.

Syirâzî, Abû Ishâa al-. Al-Muhadzdzab fi al-Fiqh al-Imâm al-Syâfi'î. Beirut: Dâr al-Fikr, T.tp.

Siddiqui, Shamim Ahmad. "Factors of Production and Factor Returns Under Political Anonim, Economy of Islam", Islamic Econ, Vol. 8 (1996), pp. 3-38.

Sijistânî, Abu Dâwud al-. Sunan Abû Dâwud. Beirut: Dâr al-Fikr, T.tp.

Suhariningsih, Tanah Terlantar: Asas dan Pembaharuan Konsep Menuju Penataan. Jakarta: Prestasi Pustaka, 2009.

Sumardjono, Maria S.W. Kebijakan Pertanahan antara Regulasi dan Implementasi. Jakarta: Penerbit Buku Kompas, 2005. 
--------. Tanah dalam Perspektif Hak Ekonomi, Sosial dan Budaya. Jakarta: Penerbit Buku Kompas, 2008.

Tucker, Mary Evelyn and A. Grim, John. "Introduction: The Emerging Alliance of World Religions and Ecology" Deadalus. (130, 4, 2001).

Ya'qûb ibn Ibrâhim, Abû Yûsuf. Kitab al-Kharraj. Pakistan: Idârah alQur'ân wa al-'Ulûm al-Islâmiyah, 1987.

Zhâhirî, Saîd ibn ㅂazm al-. al-Muhalla, Beirut: Dâr al-Âfâq al-Jadîdah, T.tp. 